\title{
ON SEVERAL NEW GENERA AND SPECIES OF AUSTRALIAN HYMENOPTERA CHALCIDOIDEA.
}

BY A. A. GiraUlt, BRISBANE, AUSTRAlia.

The following genera and species were included within three small collections of this super-family, loaned to me for study, but do not include all of the material from them. Two of these collections were from Queensland, the third partly from Victoria and partly from New South Wales.

Family Chalcididæ.

Subfamily Chalcidinæ.

Tribe Chalcidini.

Genus Tumidicoxa Girault.

\section{Tumidicoxa rufiventris new species.}

Female: Length, $5 \mathrm{~mm}$.

Opaque black, the abdomen rufous or orange red, as are also the antennal flagellum, the posterior coxæ, tibiæ (except at tip) and femora (except at apex, lateral), the cephalic tibiæ, except at base, and all the tarsi (somewhat diluted with yellowish); cephalic and intermediate coxæ black or very dark, the proximal half or more of the cephalic and intermediate femora black, their distal half or less honey yellow. Scape dark fuscous, the pedicel somewhat lighter. Tegulæ, a rounded spot at apex of posterior femur laterad, a distinct oval spot near tip of posterior tibiæ and the knees more or less lemon yellow. Wings very slightly stained throughout, the venation smoky. Pubescence not conspicuous, with a reddish tinge.

Scrobicular cavity nearly smooth, shining; head and thorax rugoso-punctate, the propodeum mesad (dorsal aspect) foveate, the abdomen glabrous, but the distal segments finely, polygonally sculptured. Lateral ocelli distinctly more than their own diameter from the eye margin. Plate at apex of scutellum distinctly bilobed. Propodeum in the dorso-lateral aspect, with at least one tooth-like projection, its lateral aspect moderately hairy, but not conspicuously so. Posterior femora with one moderately large tooth, followed by about ten others, which are smaller distad, all the ten much smaller than the first. Antennæ 12 -jointed, the single ring-joint large, the pedicel as long as the first funicle 
joint, which is somewhat wider than long, the remaining joints all wider than long, except the distal club joint, which is longest, conical; distal funicle joints transverse; flagellum clavate, somewhat compressed.

(From two specimens, two-thirds of an inch objection, 1-inch optic, Bausch and Lomb.)

Male: Not known.

Described from two female specimens mounted on pins, labelled "Warburton, Victoria." This species differs from the South American forms strikingly in coloration; also the funicle joints of the antennæ are shorter, the pedicel longer in relation to them, the lateral ocelli farther away from the eyes, the plate of the scutellum more deeply lobed and the stigmal vein not sessile, yet short. Otherwise, it is similar in all details, with the possible exception of the ventral plate on the thorax, which I was unable to see in these specimens because of the manner in which they were mounted.

Habitat: Australia-Warburton, Victoria.

Types: No. Hy 1178, Queensland Museum, Brisbane, the above specimens ( 2 pins) plus a slide bearing an antenna and a posterior leg.

2. Tumidicoxa flavipes new species.

Female: Length, about $5 \mathrm{~mm}$.

Like the South American species, but the plate at the apex of the scutellum is not emarginate at the meson, or barely so. Opaque black marked with lemon yellow as follows: The tegulæ except at extreme base (cephalad), tibiæ and tarsi, except the brownish base of posterior tibia and parts of the distal tarsal joint, distal half of cephalic femora, distal third of intermediate femora and the tip of the posterior femora. Legs otherwise black, reddish black on femora and tibiæ on first two legs. Venation and antennæ brownish black, the latter really black, brownish toward tip. Wings perfectly clear. Body rugoso-punctate, the second abdominal segment shining. Pubescence not conspicuous. Antennæ 12 -jointed, cylindrical, with one ring-joint, the pedicel small, wider than long, not half the length of the proximal funicle joint, which is the longest joint of the flagellum. Distal club joint longer than the other, obliquely truncate at tip. Distal 
funicle joint slightly wider than long, the middle joints subquadrate. Scape short, simple. Posterior femora beneath the others, the last three distinctly smaller in succession, the last very small. The teeth are black, and they rather increase in size at the middle (Nos. 5, 6 and 7 from proximal end). Posterior femur minutely punctulate and clothed with soft, greyish pubescence. Agreeing with the generic description, except as may have been noted. The lateral ocelli are somewhat farther away from the eyes.

(From a single specimen, the same magnification.)

\section{Male: Not known.}

Described from a single pinned female labelled "Dandenong Range, Victoria."

Habitat: Australia-Victoria (Dandenong Mountains).

Type: No. Hy 1179, Queensland Museum, Brisbane, the above specimen on a card; an antenna on a slide.

3. Tumidicoxa victoria new species.

Male: Length, $6.1 \mathrm{~mm}$.. Rather large.

Like the preceding species, but larger, more robust, the plate at the apex of the scutellum plainly bidentate, the scape longer, the black parts of the legs darker, and specifically the cephalic tibiæ are brown in the middle, the intermediate ones along the proximal half, except at base and the posterior ones, black in the middle, their tips pale yellowish. The posterior fermora beneath bear nearly the same arrangement of teeth, but there are only eleven, followed by a minute tubercle; numbers 3 and 4 are larger than 2 and those distad of them. The posterior coxæ have a flabellate enlargement at the apex above. The antennæ 12 -jointed, the distal funicle joints more transverse than with flavipes. Wings hyaline.

(From a single specimen, the same magnification.)

Female: Not known.

Described from a single male, minutien-mounted and labelled "Dandenong Ranges, Victoria."

Habitat: Australia-Victoria (Dandenong Mountains).

Type: No. Hy 1180, Queensland Museum, Brisbane, the above specimen plus an antenna on a slide.

4. Tumidicoxa regina new species.

Male: Length, $4.95 \mathrm{~mm}$. 
Like flavipes, but more robust, the scutellum terminating in a distinctly bidentate plate and the postmarginal vein longer. The scape is also longer. Posterior femur armed with twelve teeth, the first large, the next two very small, followed by seven larger ones, (of which numbers six to nine are largest) and two shorter ones, the last broad, its flat upper edge at apex thus emarginate; excluding the first tooth, numbers 6 to 9 are largest. In flavipes, teeth Nos. 2 and 3 are not distinctly smaller than the ones immediately following (distad).

(From one specimen, the same magnification.)

Female: Not known.

Described from a single male specimen on a pin, from the collections of the Queensland Museum, labelled "Brisbane, H. Hacker. 3-7-11."

Habitat: Australia-Brisbane, Queensland.

Type: No. Hy 1181, Queensland Museum, Brisbane, the forenoted specimen on a pin, plus one slide bearing antennæ and a posterior leg.

\section{Pseudepitelia new genus.}

Female: Resembling Epitelia of Kirby, but the abdomen not produced into a stylus distad, the posterior femora without depressed punctures and armed beneath with more teeth, there being six moderately large, more or less, subequal teeth (but the first largest), followed distad by four others, which shorten in succession. The antennæ are 13-jointed, with one ring-joint, inserted nearly on a line with the ventral ends of the eyes. the scrobicular cavity reaching the cephalic ocellus, the lateral ocelli plainly more than their own diameter from the eye margin. The postmarginal vein about half the length of the marginal, slender, the stigmal very short, yet with more or less of a distinct neck. The second abdominal segment occupying more than a third of the abdomen. Propodeum with two small, acute projections in the middle of the dorso-lateral line (seen from ventro-laterad). Body nonmetallic, punctate. Abdomen as in Chalcis. The scutellum terminates in a short, bidentate plate.

Male: Not known.

Type: The following species. 
1. Pseudepitelia rubrifemur new species.

Female: Length, $5.10 \mathrm{~mm}$.

Opaque black, the second abdominal segment glabrous black, the posterior femur dark reddish, the venter of the abdomen at the meson more or less suffused with dark reddish or yellowish; tegulæ pallid, the wings hyaline, the venation black, face and distal half of the abdomen pubescent. Tarsi more or less brownish. Intermediate and cephalic knees and two distinct elongate spots on each end of the posterior tibiæ exteriorly and not at tip, pale yellowish. Antennae wholly black.

Body moderately finely, densely punctate, the spaces between the punctures lined. First abdominal segment, with very minute punctures, which vary in size, the following segments pubescent and transversely wrinkled, the penultimate segment rougher. Posterior femora densely punctulate the punctures very minute; antennæ, with the distal joint very short, truncate, only about twice the length of the ring-joint; scape very long, narrowing distad; pedicel much longer than the ring-joint, but only half the length of the proximal funicle joint, which is longest of the funicle, twice the length (or nearly) of the subquadrate distal funicle joint. Proximal two joints of the club subequal, the distal joint flat, very short.

(From one specimen, the same magnification.)

Male: Not known.

Described from a single cardmounted female, labelled "Cheltenham, Victoria."

Habitat: Australia-Victoria (Cheltenham).

Type: No. Hy 1182, Queensland Museum, Brisbane, the above specimen, plus a slide bearing an antenna and a posterior leg.

2. Pseudepitelia tricolor new species.

Female: Length, $5.00 \mathrm{~mm}$.

The same as rubrifemur, but the postmarginal vein shorter and stouter, the second (distal) elongate, pale yellowish spot exteriorly on posterior tibia absent, but the two proximal tarsal joints (and less so, the third) of posterior legs white, suffused with 
yellowish; the scutellum has not a small patch of greyish pubescence at apex, just above the terminal plate as with the type specimen (rubrifemur) and in tricolor the third abdominal segment is more roughly finely sculptured. There are eleven distinct teeth on the posterior femur instead of the ten of the type species. Intermediate and cephalic tarsi white or whitish. (Antennæ missing; scape black.) Wings hyaline.

(From a single specimen, the same magnification.)

Male: Not known.

Described from a single cardmounted specimen from the collections of the Queensland Museum, labelled "Q.M. Tambourine. H. Hacker, April 2, 1911."

Habitat: Australia-Tambourine, Queensland.

Type: No. Hy 1183. Queensland Museum, Brisbane, the above female on a card.

Brachepitelia new genus.

Female: The same as the preceding genus, Pseudepitelia, but the antennæ 12 -jointed, the scutellum terminating in a short plate, whose distal margins are straight, the plate barely differentiated, The submarginal vein is shorter and stouter. Propodeum without noticeable lateral projections. Second abdominal segment occupying nearly half of the abdomen.

Male: Not known.

Type: The following species.

1, Brachepitelia rubripes new species.

Female: Length, $3.70 \mathrm{~mm}$.

Opaque black, marked with dark red as follows: Posterior legs except coxæ; cephalic knees, tibiæ and tarsi; intermediate knees and tarsi (mixed with brownish) and the ends of the tibiæ. Venation dark, the wings hyaline. Head and thorax rugoso-punctate. Posterior femur with ten distinct teeth, the first twice the largest, the distal teeth smaller in succession.

Male: Not known.

Described from a cardmounted female, labelled "Larva of Various Moths, Melbourne."

Habitat: Australia-Melbourne, Victoria.

Type: No. Hy 1184, Queensland Museum, Brisbane, the above specimen; an antenna on a slide.

(To be continued.) 


\section{$2 \mathrm{BHL}$ Biodiversity Heritage Library}

Girault, Alexandre Arsène. 1913. "On several new genera and species of Australian Hymenoptera Chalcidoidea." The Canadian entomologist 45, 101-106. https://doi.org/10.4039/Ent45101-4.

View This Item Online: https://www.biodiversitylibrary.org/item/22231

DOI: https://doi.org/10.4039/Ent45101-4

Permalink: https://www.biodiversitylibrary.org/partpdf/27086

\section{Holding Institution}

MBLWHOI Library

\section{Sponsored by}

MBLWHOI Library

\section{Copyright \& Reuse}

Copyright Status: NOT_IN_COPYRIGHT

This document was created from content at the Biodiversity Heritage Library, the world's largest open access digital library for biodiversity literature and archives. Visit BHL at https://www.biodiversitylibrary.org. 